\title{
RAPID IDENTIFICATION OF CELL WALL COMPONENTS AS A GUIDE TO THE CLASSIFICATION OF AEROBIC CORYNEFORM BACTERIA FROM HUMAN SKIN
}

\author{
D. G. PITCHER \\ Institute of Dermatology, St John's Hospital for Diseases of the Skin \\ Homerton Grove, London E9 6BX
}

THE taxonomy of aerobic coryneform bacteria has been beset by problems since the early days of skin microbiology. The chief difficulty has been that schemes based on classical tests have revealed an immense number of biotypes that can be grouped only in an arbitrary way. Generally, the correlation of an ecological observation with a test or set of tests has been the prime consideration (Evans, 1968; Marples, 1969; Somerville, 1973). As coryneform bacteria are ubiquitous in nature, they must frequently come into contact with exposed human skin and may remain there for some time; taxonomic schemes may be confused by the inclusion of such organisms.

The term coryneform is used throughout this paper in the sense defined by Cowan (1968) to cover all gram-positive, non-sporing, pleomorphic rods and is analogous to the use of the term " coliform". The medical term "diphtheroid" is avoided because it implies a closer resemblance to Corynebacterium diphtheriae than that possessed by many coryneforms.

Probably the most significant contribution to the classification of coryneform bacteria was the recognition of cell wall analysis as a valuable taxonomic tool (Cummins and Harris, 1956, 1958). It was later shown (Cummins, 1962) that antigenic studies supported the relationships suggested by cell wall analysis, and that the genus Corynebacterium was heterogeneous in its construction, though $C$. diphtheriae and closely related corynebacteria had very similar wall compositions.

Considerable information can be obtained, and large numbers of isolates can conveniently be examined by analysing whole-cell hydrolysates instead of purified cell-wall preparations. This approach is often possible (Stanneck and Roberts, 1974) because scme cell-wall constituents such as neutral sugars are present in large amounts, while others such as diamino acids occur in the cell wall only; moreover, protein-derived ornithine and lysine and nucleic acid pentose are the only substances present in whole-cell hydrolysates in quantities sufficient to lead to confusion with any cell wall constituent.

The characteristic constituents of the cell walls of corynebacteria are meso diaminopimelic acid (DAP) and arabinose (Cummins and Harris, 1958) and the resident coryneforms of the skin have long been assumed, without proof, to belong to the genus Corynebacterium. A survey of the principal wall components of 1005 coryneform bacteria of the skin was therefore carried out.

\section{MATERIALS AND METHODS}

Strains. In all, 1005 isolates were studied. Coryneforms isolated in this laboratory were from the following sources: healthy adults (nine sites, 328 isolates); adult patients in a ward

Received 29 Oct. 1976; revised version accepted 29 Apr. 1977

J. MED. MICROBIOL. - VOL. 10 (1977) 
for skin diseases (nine sites, 207 isolates); healthy schoolchildren (two sites, 167 isolates); patients presenting with tinea pedis (one site, 120 isolates). Isolates received from other laboratories (some from unspecified sites) included the following: 88 from haemodialysis patients (seven sites) and 21 from post-operative wounds and ulcers (Prof. R. van Furth, Leiden); 13 from patients with tinea pedis in the U.S.A. (Dr J. J. Leyden, Philadelphia); 14 porphyrin-producing isolates (Dr D. A. Somerville-Millar, Glasgow); 28 from normal adults in Poland (Dr A. Kasporowicz, Krakow); four from leprosy lesions (Dr J. Stanford, London); 11 from blood cultures (Dr F. Pagan, London); four from the blood of endocarditis patients (Dr D. McGechie, Sheffield).

Culture and purity checks. Each isolate was examined for purity by culture on $5 \%$ horse serum agar, incubated aerobically at $37^{\circ} \mathrm{C}$ for $48 \mathrm{~h}$. Coryneform morphology was checked by Preston and Morrell's modification of Gram's stain (Cowan and Steel, 1965). Nutrient broth, inoculated with a single colony, was incubated for $48 \mathrm{~h}$ and then spread on a serum agar plate to produce a lawn culture. After sufficient growth had occurred, the plate was flooded with $10 \%$ formalin, the cells were scraped off with a spatula, transferred to a centrifuge tube and centrifuged at $1500 \mathrm{~g}$ for $10 \mathrm{~min}$. The pellet was washed twice with distilled water and resuspended in $1 \mathrm{ml}$ water. Half the suspension was transferred to a freeze-drying tube and the remainder was left in the centrifuge tube. Both tubes were centrifuged and the pellets were dried in vacuo over phosphorus pentoxide.

Amino acid analysis. To the residue in the freeze-drying tube was added $0.5 \mathrm{ml}$ of $6 \mathrm{~N} \mathrm{HCl}$; the tubes were then sealed and the contents hydrolysed for $16 \mathrm{~h}$ in an oven at $100^{\circ} \mathrm{C}$. After cooling, the tube was opened and centrifuged, and the supernate was transferred to a glass phial and dried in vacuo over phosphorus pentoxide and sodium hydroxide pellets. The resulting deposit was dissolved in $0.2 \mathrm{ml}$ of $10 \%$ aqueous 2-propanol for chromatography of diamino acids.

Neutral sugar analysis. The pellet remaining in the centrifuge tube was acidified with $1 \mathrm{ml}$ of $2 \mathrm{~N} \mathrm{H}_{2} \mathrm{SO}_{4}$ and placed in a boiling water bath for $2 \mathrm{~h}$ with a "cold finger" stopper fitted to reduce evaporation. When cooled, sufficient barium carbonate was added with mixing to render the solution neutral to $\mathrm{pH}$ indicator paper. The tube was centrifuged and the supernate transferred to a small phial and dried in vacuo over phosphorus pentoxide. This residue was dissolved in $0.2 \mathrm{ml}$ of $10 \%$ aqueous 2-propanol for chromatography of neutral sugars. Chromatographic methods for both amino acids and sugars were those described by Rhuland et al. (1955) and Cummins and Johnson (1971).

Standard compounds. As a guide to the identification of spots, a number of diamino acids and neutral sugars were run on chromatograms in parallel with the samples. The diamino acids were: 2,4 diaminobutyric acid (DAB); 2,6 diaminopimelic acid (DAP) (a mixture of $L L$ and meso isomers); lysine; ornithine. The presence of the last two as wall components could only be inferred by the absence of DAP and DAB as they occur in intracellular proteins and therefore could not be identified from whole-cell hydrolysates. The neutral sugars were arabinose, galactose, glucose, mannose, fucose, rhamnose and ribose. Galactose and glucose were sometimes difficult to distinguish on chromatograms, and spots with $\mathbf{R} f$ values corresponding to either of these sugars are referred to as $\mathbf{G}$. A spot corresponding to ribose was found on all sugar chromatograms. This was derived from the hydrolysis of nucleic acids and was ignored in the analysis of results.

\section{RESULTS}

A fairly consistent pattern was seen in the distribution of different coryneform cell-wall types from the various sources. In every batch of coryneforms studied over a 3-year period, the most common type had the pattern meso DAP with arabinose (table I). This pattern is associated with the genus Corynebacterium as described by Buchanan and Gibbons (1974) and represents the " type-IV wall" ascribed to Corynebacterium, Nocardia and Mycobacterium by Lechevalier and Lechevalier (1970). The latter two genera are usually 
TABLE I

The major cell-wall components of coryneforms in relation to the human source of the isolates

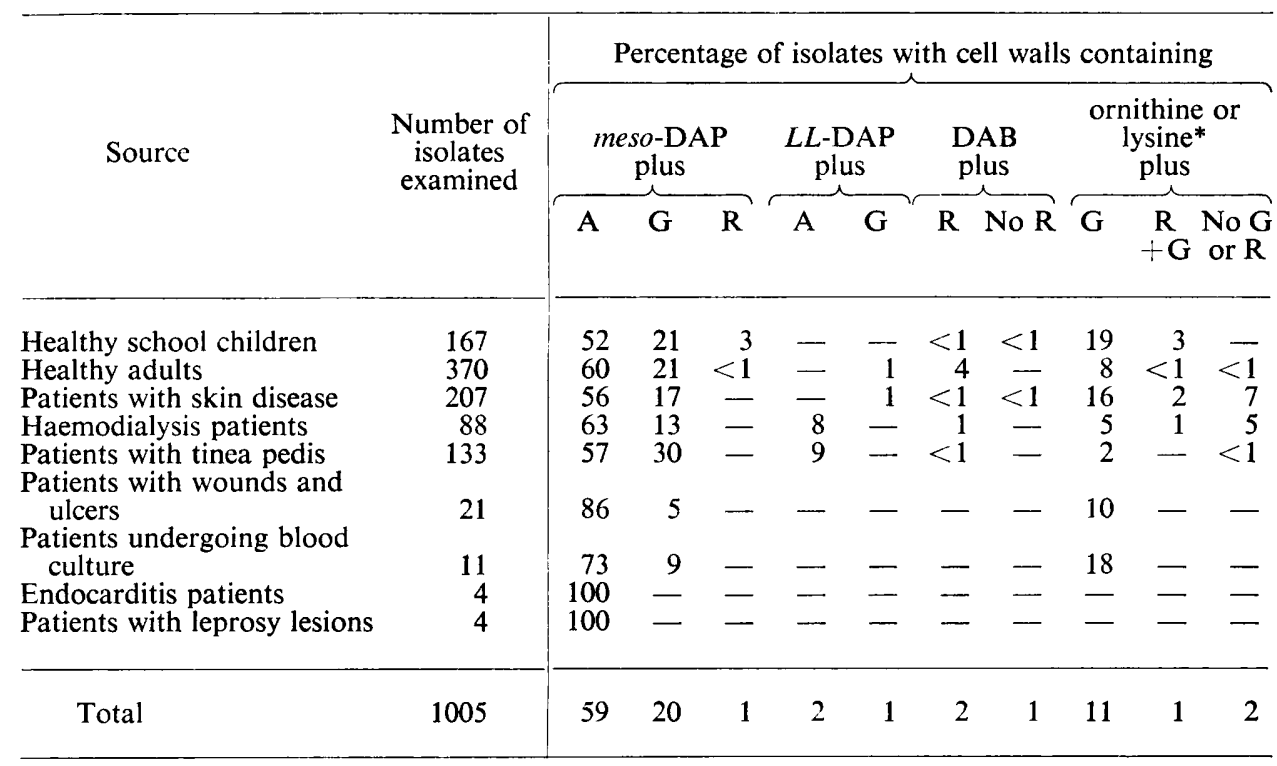

$A=$ Arabinose $; \mathbf{R}=$ rhamnose $; \quad G=$ glucose or galactose or both; $D A B=2,4$ diaminobutyric acid; $\mathrm{DAP}=2,6$ diaminopimelic acid.

$*=$ Inferred from absence of DAB and DAP.

distinguishable from coryneforms on morphological grounds. The second most-frequent type had the cell wall pattern meso DAP with G; galactose on its own was the spot most frequently seen when separation was clear. This type was isolated from $13-30 \%$ of samples obtained from the first five sources (all skin) listed in table I, but was less frequently isolated from blood, wounds, ulcers and leprotic lesions. The combination rhamnose plus DAP was rarely found. The third most-frequent type of coryneform did not have DAP, DAB or arabinose and may therefore have contained lysine or ornithine. Considerable variation occurred in respect of the sugar content of cell walls, but glucose or galactose, with or without rhamnose, was the most frequent combination. Organisms possessing this combination were more than twice as common in healthy children and skin patients than in healthy adults or haemodialysis patients. Of the remaining cell-wall types, only one was of interest and that possessed $L L$ DAP with arabinose. Other investigations have shown that such coryneforms are a unique and homogeneous group (Pitcher, 1976).

Table II shows the percentages of cell wall types isolated from various parts of the body. A clear difference emerges in comparing the totals for exposed sites and intertriginous sites. The sites that would be expected to be contaminated from the environment most easily are the hands and forehead and these yielded a high percentage of isolates with cell walls containing ornithine or lysine, but a lower percentage of type-IV isolates than any other site. The reverse was true of the intertriginous sites. 
TABLE II

The major cell-wall components of coryneforms in relation to the parts of the body from which the isolates were obtained

\begin{tabular}{|c|c|c|c|c|c|c|c|c|c|c|c|}
\hline \multirow{3}{*}{ Site } & \multirow{3}{*}{$\begin{array}{l}\text { Number of } \\
\text { isolates } \\
\text { examined }\end{array}$} & \multicolumn{10}{|c|}{ Percentage of isolates with cell walls containing } \\
\hline & & \multicolumn{3}{|c|}{$\begin{array}{l}\text { meso-DAP } \\
\text { plus }\end{array}$} & \multicolumn{2}{|c|}{$\begin{array}{c}L L \text {-DAP } \\
\text { plus }\end{array}$} & \multicolumn{2}{|c|}{$\begin{array}{l}\text { DAB } \\
\text { plus }\end{array}$} & \multicolumn{3}{|c|}{$\begin{array}{l}\text { ornithine or } \\
\text { lysine* } \\
\text { plus }\end{array}$} \\
\hline & & A & G & $\mathbf{R}$ & A & G & $\mathbf{R}$ & No $R$ & G & $\begin{array}{c}R \\
+G\end{array}$ & $\begin{array}{l}\text { No G } \\
\text { or } R\end{array}$ \\
\hline Nose & 66 & 70 & 8 & 一 & 2 & - & 2 & 2 & 18 & - & - \\
\hline Chest & 52 & 65 & 15 & 2 & 4 & - & - & - & 8 & - & 6 \\
\hline Forehead $\dagger$ & 101 & 33 & 24 & - & - & $<1$ & 2 & - & 30 & 7 & - \\
\hline Eart & 28 & 46 & 14 & - & - & - & - & - & 30 & 4 & 7 \\
\hline Fore & 44 & 55 & 25 & - & - & 2 & - & - & 18 & - & - \\
\hline Har & 74 & 33 & 33 & - & 1 & 1 & - & - & 23 & 4 & - \\
\hline Leg $\dagger$ & 57 & 58 & 16 & 2 & 2 & - & - & 2 & 19 & 2 & - \\
\hline Axi & 249 & 69 & 15 & $<1$ & $<\overline{1}$ & - & 3 & - & 8 & $<\overline{1}$ & $<1$ \\
\hline Perineum $\ddagger$ & 51 & 67 & 22 & - & - & - & - & - & 8 & - & 4 \\
\hline Toew & 196 & 61 & 25 & - & 7 & - & 1 & $<1$ & 2 & 4 & - \\
\hline Exposed sites (total) & 304 & 43 & 25 & $<1$ & $<1$ & 1 & 1 & $<1$ & 25 & 4 & 1 \\
\hline Intertriginous sites (total) & 496 & 66 & 20 & $<1$ & 3 & - & 2 & $<1$ & 6 & 2 & $<1$ \\
\hline
\end{tabular}

$A=$ Arabinose; $R=$ rhamnose; $G=$ glucose or galactose or both; $D A B=2,4$ diaminobutyric acid; $\mathrm{DAP}=2,6$ diaminopimelic acid.

*=Inferred from the absence of DAB and DAP.

$\dagger=$ Exposed site.

$\ddagger=$ Intertriginous site.

Isolates of the meso-DAP-G type showed a fairly even distribution between the sites, but the nose yielded the fewest. This site was unusual in yielding the highest percentage of type-IV isolates and a percentage of ornithine or lysine types comparable with that found in exposed sites.

\section{DISCUSSION}

Cell wall analysis is accepted as a useful taxonomic procedure, especially for coryneforms. For example, the presence of meso-DAP with arabinose is indicative of a Corynebacterium species of animal origin (Cummins and Harris, 1958). The other patterns described here are less clearly related to ecological characteristics.

The pattern meso-DAP plus galactose was found in coryneforms isolated from cheese by Sharpe, Law and Phillips (1976), who incriminated human skin as a possible source of their strains on the grounds of high salt tolerance and ability to grow at temperatures above $37^{\circ} \mathrm{C}$. These strains may be closely related to the isolates of similar wall composition commonly recovered in the present study, some of which in common with the cheese strains, produce methane thiol.

The orange cheese-coryneform, Brevibacterium linens, also has the wall pattern meso-DAP plus galactose and produces methane-thiol (Sharpe, et al., 1977). It was listed by Breed, Murray and Smith, (1957) as the type species 
of the genus Brevibacterium. However, members of this genus are now considered species incertae sedis (Buchanan and Gibbons, 1974) and coryneforms with a wide variety of cell wall patterns fall under this heading.

Coryneform bacteria with DAB in their cell walls are principally found as plant pathogens, but Corynebacterium aquaticum, which has been found in tap water and in the blood of a patient with septicaemia (Weiner and Werthamer, 1975) also has this amino acid (Yamada and Komagata, 1970). In view of the small percentage of isolates with $\mathrm{DAB}$ encountered in this study, and the variety of accompanying sugar patterns, these strains would seem to be incidental skin contaminants.

The diamino acid, lysine, occurs commonly in the coryneform flora of the environment, but is also found in the animal pathogens $C$. pyogenes and $C$. haemolyticum, both of which also possess rhamnose. These organisms may sometimes be found on skin, but their inclusion in the genus Corynebacterium is controversial (Barksdale, 1970). It is probable that most of the isolates containing lysine or ornithine in the present study were environmental in origin. They were isolated more frequently from exposed skin sites than from intertriginous sites, whereas the reverse was true of the type-IV wall coryneforms. The percentage of meso-DAP-G types from exposed sites was slightly higher than that from intertriginous sites. It is possible that some of these organisms were derived from the environment, but that most were skin residents.

The percentages of type-IV coryneforms in table I range from 52 to 63 for the majority of sources. As coryneforms isolated from blood, wounds, ulcers and leprotic lesions showed a range of 73-100\% for type IV, such organisms may occur as opportunist colonisers more readily than other types, but in view of the small number of isolates tested no firm conclusions can be drawn.

The skin patients were not known to have bacterial skin diseases and one difference between them and the adults and haemodialysis patients studied was that, though they led fairly sedentary lives in the ward, large areas of their skins were frequently exposed to the atmosphere to keep their lesions dry, and this may have permitted contamination from the environment. The high percentage of isolates without DAP or DAB from children may have been because only two sites (axilla and forehead) were sampled, whereas nine sites were sampled in the adults and skin patients, and seven in the haemodialysis patients (see table I). The forehead, a very exposed site, contributed approximately half of the isolates in this category. If the approximate figure $(19 \%)$ is compared with that for the tinea pedis patients a striking difference is seen; the toewebs are relatively inaccessible to contaminants from the environment.

The survival of environmental coryneforms on the skin may be governed by a number of factors. Exposed and intertriginous sites differ in several respects such as the distribution of sweat glands and sebaceous follicles and the type of sweat. For example, apocrine glands occur in addition to eccrine glands in the axilla and perineum and bacterial nutrients thus vary in availability. The forehead is particularly rich in lipid material that favours the growth of many coryneforms, but unlike the covered sites it has a low humidity and this represents a serious threat to bacterial survival. 
In short, of the various coryneform bacteria isolated from the skin, a substantial majority could be assigned to the genus Corynebacterium on the basis of cell wall composition. However, a significant proportion could not be so placed; those with a cell wall resembling that of Brevibacterium linens may have been members of the resident flora of the skin. Strains that did not possess meso-diaminopimelic acid were distributed erratically between the various kinds of sample, but were more common on skin sites accessible to the environment (table II). Thus although they may sometimes colonise skin, their origin is probably environmental.

As the bacterial residents of human skin include at least two genera of coryneforms and a wide variety of contaminants, it is essential that taxonomic schemes based on classical tests should only be attempted when the coryneforms under investigation have been allotted to one of the taxa described here. At present the only convenient way of doing this with large numbers of isolates is by the chromatographic analysis of whole-cell hydrolysates for major cellwall components.

\section{SUMMARY}

In a survey of over 1000 isolates of aerobic skin coryneforms from a wide variety of sources, chromatographic methods were used to identify the major cell-wall components in whole-cell hydrolysates.

Most of the skin isolates-like members of the genus Corynebacteriumpossessed meso-diaminopimelic acid and arabinose. However, substantial numbers of coryneforms apparently resident on the skin did not have this pattern; the sites from which they were isolated suggested that some were derived from the environment whilst others (possessing meso-DAP and galactose but not arabinose as major wall components) were members of the resident skin flora.

I am indebted to J. McL. Philp (Unilever Research) and latterly to the Medical Research Council for support and I am grateful to all those named in the text who donated isolates of coryneforms.

\section{REFERENCES}

Barksdale, L. 1970. Corynebacterium diphtheriae and its relatives. Bact., Rev., 34, 378.

BreEd, R. S., MurRay, E. G. D. AND SMITH, N. R. 1957. Bergey's manual of determinative bacteriology, 7th ed., Baltimore.

Buchanan, R. E. AND GibBons, N. E. 1974. Bergey's manual of determinative bacteriology, 8th ed., Baltimore.

Cowan, S. T. 1968. A dictionary of microbial taxonomic usage, Edinburgh.

Cowan, S. T. AND Steel, K. J. 1965. Manual for the identification of medical bacteria, Cambridge.

Cummins, C. S. 1962. Chemical composition and antigenic structure of cell walls of Corynebacterium, Mycobacterium, Nocardia, Actinomyces and Arthrobacter. J. gen. Microbiol., 28,35 .

Cummins, C. S. AND Harris, H. 1956. The chemical composition of the cell wall in some Gram-positive bacteria and its possible value as a taxonomic character. J. gen. Microbiol., 14, 583.

Cummins, C. S. AND Harris, H. 1958. Studies on the cell wall composition and taxonomy of actinomycetales and related groups. J.gen. Microbiol., 18, 173. 
Cummins, C. S. And Johnson, J. L. 1971. Taxonomy of the clostridia: wall composition and DNA homologies in Clostridium butyricum and other butyric acid-producing clostridia. J. gen. Microbiol., 67, 33.

Evans, N. M. 1968. The classification of aerobic diphtheroids from human skin. Br. J. Derm. [Syph.], 80, 81.

LeChevalier, M. P. AND LeChevalier, H. 1970. Chemical composition as a criterion in the classification of aerobic actinomycetes. Int. J. syst. Bact., 20, 435.

MARPLES, R. R. 1969. Diphtheroids of normal human skin. Br. J. Derm. [Syph.], 81, Suppl. $1,47$.

PITCHER, D. G. 1976. Arabinose with $L L$-diaminopimelic acid in the cell wall of an aerobic coryneform organism isolated from human skin. J. gen. Microbiol., 94, 225.

Rhuland, L. E., Work, E., Denman, R. F. and Hoare, D. S. 1955. The behaviour of the isomers of $\alpha, \varepsilon$-diaminopimelic acid on paper chromatograms. J. Am. chem. Soc., $77,4844$.

Sharpe, M. E., Law, B. A. And Phillips, B. A. 1976. Coryneform bacteria producing methane thiol. J. gen. Microbiol., 94, 430.

Sharpe, M. E., Law, B. A., Phillips, B. A. and Pitcher, D. G. 1977. Methane-thiol production by coryneform bacteria: strains from dairy and human skin sources and Brevibacterium linens. J. gen. Microbiol., in the press.

Somerville, D. A. 1973. A taxonomic scheme for aerobic diphtheroids from human skin. J. med. Microbiol., 6, 215.

STANNECK, J. L. AND RoberTS, G. D. 1974. Simplified approach to identification of aerobic actinomycetes by thin-layer chromatography. Appl. Microbiol., 28, 226.

Weiner, M. AND Werthamer, S. 1975. Corynebacterium aquaticum septicaemia: characterisation of the microorganisms. Am. J. clin. Path., 64, 378.

Yamada, K. And Komagata, K. 1970. Taxonomic studies on coryneform bacteria. II. Principal amino acids in the cell wall and their taxonomic significance. J. gen. Appl. Microbiol., 16, 103. 